\title{
The Outcomes of the Implementation of Internet of Things: A Public Value Perspective
}

\author{
Ott Velsberg ${ }^{(\bowtie)}$ \\ Department of Informatics, Umeå University, Umeå, Sweden \\ ott.velsberg@umu.se
}

\begin{abstract}
In recent years, Internet of Things (IoT) has gained presence in all areas of life. Whilst private sector is the forerunner in the adoption of these devices, public sector usage has been lagging. With the rise of smart initiatives, public organizations are increasingly implementing IoT. The necessity to know in which areas of public sector IoT has been implemented and what public value has been derived, has gained importance as reporting of the cost efficiency and benefits of these initiatives has gained attention. This paper seeks to determine the importance of IoT in the public sector from the perspective of public value. IoT implementation in Estonian municipalities was studied to provide concrete data on the use of IoT. Next to efficiency, which is a known goal of IT implementation, the research findings suggest that while IoT has generated public value, there has been a shift in value creation with other outcomes such as effectiveness, transparency and collaboration gaining increased presence. While IoT shows great promise for public value creation, more research is needed to study how public sector can leverage these devices to harvest more benefits than the simple automatization of work processes.
\end{abstract}

Keywords: Public values $\cdot$ Public sector $\cdot$ Value creation $\cdot$ Internet of Things

\section{Introduction}

The term Internet of Things (IoT) has attracted considerable attention in academics, industry and public sector, and is envisioned as a global network of machines and devices that can interact with each other [23]. The IoT has been regarded as one of the most important areas of future technology [23] and to be at the core of the fourth industrial revolution [19]. The European Commission envisions IoT as an indispensable component towards the digitisation of our society and economy [8]. It is forecasted that the market value of IoT in the EU will exceed one trillion euros by 2020 [7], and by 2025 the yearly global economic impact of IoT is estimated to be between 3 trillion to 9 trillion euros, accounting close to $11 \%$ of the world economy [25].

Research indicates that by 2020 , close to $26 \%$ of all IoT solutions will be consumed by public sector [12]. A high rate of expenditure can be predicted, as national and local governments have been voracious consumers of information technologies (IT) in the past [29]. However, recent studies indicate that close to $60 \%$ of IoT initiatives stall at the Proof of Concept stage and $75 \%$ of completed IoT projects fail to produce value 
[16]. With regards to this, it becomes questionable whether the value created from IoT overweighs the financial risks taken by the public sector.

Creating public value has been a key focus in digitizing public sector organizations. If the public sector continues to invest in IoT, our innate logic tells us that it must create public value. Agarwal and Lucas [1] argued that to contribute to the IS field it is fundamental to demonstrate the value of IT. Following the same argumentation, it is crucial to demonstrate the public value of IoT. However, to date, the research on IoT and public value creation has been scarce.

The aim of this research is to offer a contribution regarding the public value created by IoT, asking: What public value does IoT create in the public sector? The study offers a glimpse on the main values created by IoT, based on an extensive qualitative study on 46 municipalities in Estonia. The paper briefly introduces the concept of public value and IoT, including an overview of IoT implementation in the public sector.

The paper is structured as follows. First, the theoretical basis is set by introducing the concept of public value. Next, the concept of IoT and its role in public sector will be introduced. In the following parts, the research design and findings are presented. This will be followed by a discussion of findings and a conclusion.

\section{Theoretical Background}

This section introduces the concept of public value, which is regarded as one of the main reasons for public sector innovation. The following section introduces the concept of IoT and discuss its importance in generating public value.

\subsection{Public Value Perspective}

Public entities such as governments, municipalities and county councils are constantly seeking to address contemporary challenges and opportunities through utilizing emerging technologies [29]. While there are many motivators for adopting IT solutions, a primary goal of IT initiatives is to create and deliver public value [18]. Public value focuses on governmentally produced benefits that serve the interests of stakeholders both inside and outside the public organization [14]. The creation of public value entails balancing competing public interests through emphasizing collective preferences and expectations of government, citizens and other stakeholders who consume the services $[5,27]$. Consequently, public sector bases its decisions to implement IT on the expected benefits and conflicting demands of various stakeholders [30].

It is widely acknowledged that IT creates public value. A successful IT implementation is believed to drastically change how governmental organizations operate, bringing forth substantial organizational, technical, business and societal benefits [10, 20]. IT-based value manifests itself both in terms of economic values e.g. operational efficiency, and non-economic values e.g. trust in government and sustainability [29]. For the associated stakeholders, e.g. citizens, users, public administrators and politicians, the public value can manifest differently, e.g. administrative personnel and managers from public sector might place high value on accountability, c.f. [10], while 
citizens might value accessibility to governmental information [38]. Harrison et al. [14] divided public value into seven categories, namely:

1. Economic - impacts on current or future income, asset values, liabilities, entitlements, or other aspects of wealth or risks to any of the above.

2. Political - impacts on a person's or group's influence on government actions or policy, or their role in political affairs, influence in political parties or prospects for public office.

3. Social - impacts on family or community relationships, social mobility, status, and identity.

4. Strategic - impacts on person's or group's economic or political advantage or opportunities, goals, and resources for innovation or planning.

5. Quality of life - impacts on individual and household health, security, satisfaction, and general well-being.

6. Ideological - impacts on beliefs, moral or ethical commitments, alignment of government actions/policies or social outcomes with beliefs, or moral or ethical positions.

7. Stewardship - impacts on the public's view of government officials as faithful steward.

The incorporation of public value in the discussion of public sector investment in IT is especially relevant as it allows to monitor the outcome of government investment and understand the relationship between IT and public value delivery [36]. Understanding the relationship between IT and public value creation can assist public organizations in the pursuit of suitable use of technology to benefit society and secure the cost efficiency of public value creation [3].

\subsection{Role of the Internet of Things}

The IoT has rapidly gained presence and is sometimes regarded as the most disruptive phase of the Internet revolution [2, 34]. IoT is ubiquitous by nature and is present in different almost identical concepts, such as "Internet of Everything", "ubiquitous computing", "pervasive computing" and "ambient intelligence", whereas the differences between the terms are of academic nature [9]. IoT is a general term used for objects interconnected through networks, that encompass processing and sensor capabilities, allowing the devices to transmit recorded information from the outside environment. IoT allows information, resources, "things", e.g. sensors, beacons, actuators, mobile phones etc., to interact with each other and cooperate with their smart components to reach common goals [15]. Realizing the value of IoT requires integration of IT infrastructures and information services - such as RFID tags, wireless broadband and geographic information systems [33]. Sensory data must be gathered from distributed smart objects and be transmitted using a communication infrastructure, which can encompass both wired and wireless communication technologies [32]. IoT allows to link real-life objects with the virtual world - providing anytime, anyplace connectivity for anything [34].

These capabilities can be applied to everyday objects, thus affecting all areas of life [9]. IoT will change the way we collect, analyse, and respond to data, creating opportunities for 
individuals, governments, and businesses to develop new business models and forms of interaction that take advantage of ubiquitous computing power embedded in objects [13]. While the majority of IoT initiatives have been implemented in the private sector, studies have indicated that the importance of IoT in public sector is increasing [4, 12]. This is driven by the rapid development of IT, and expanding efforts by national and local governments to change how they operate. Local governments are increasingly turning towards new information systems, often utilizing IoT, to develop livable, economically sustainable and efficient living environments. IoT is implemented in various settings from cities to rural areas. Utilizing IoT devices allows local governments to monitor and take immediate action on almost every aspect of urban and rural space, and provide citizens with relevant information and services $[33,35]$. Among others, IoT can be used to create new and enhance existing services, improve efficiency and effectiveness of internal management and service delivery, and foster collaboration with different stakeholders [9, 22]. Due to the dynamic nature of public sector, the requirements for IoT devices can vary significantly. The IoT devices that can swiftly and accurately transmit information can be crucial for winter road maintenance, while speed would not be a requirement for water consumption monitoring.

In the context of public sector, IoT has the potential to improve several areas, including: healthcare, education, utilities, infrastructure, buildings, environment and culture. With regards to this, IoT becomes pivotal in streamlining governmental processes and engaging citizens in all areas of local governance. However, to date, little is known on how IoT generates public value. Consequently, there also lacks knowledge on how local governments could benefit from implementing IoT.

\section{Public Value Framework}

For the study in hand, it was considered suitable to use the six public value generating mechanisms proposed by Harrison et al. [14] to understand what public value IoT creates in public sector (See Table 1). Harrison et al. [14] created the set of value generators to specify how public value is created, i.e. which government action lead to the creation of public value. For analysis, the six public value mechanisms proposed by Harrison et al. [14] were used for guidance. To investigate the relationship between IoT and public value generating mechanisms, a public value framework was created to assess the IoT initiatives and to distinguish between the outcomes (See Table 1). Based on Nam and Pardo [28] the evaluation dimensions were presented from the external view (interactions with citizens, private companies and other relevant non-governmental actors) and from the internal view (interactions within the local government). Identifying and measuring the public value of IoT is complicated as different stakeholders may have different attitudes on what is regarded a successful outcome of an IT initiative [37]. As a result, public value creation was studied from the perspective of public organizations. Similarly to this study, most research on IT value studies the outcome of past IT investments through a post hoc analysis [21]. As the study is concerned with how IoT solutions add value to local governments and public, broader economic factors are not considered unless they directly relate to governmental or public impact. 
Table 1. Public value framework.

\begin{tabular}{|c|c|c|}
\hline Dimensions & Management (internal view) & Service delivery (external view) \\
\hline Efficiency & $\begin{array}{l}\text { Concentrates on the internal } \\
\text { managerial efficiency in terms of } \\
\text { obtaining increased outputs, } \\
\text { workloads, activities, processes and } \\
\text { goal attainment }\end{array}$ & $\begin{array}{l}\text { Concentrates on the efficiency of } \\
\text { producing and delivering services }\end{array}$ \\
\hline Effectiveness & $\begin{array}{l}\text { Concentrates on the quality of } \\
\text { internal management }\end{array}$ & $\begin{array}{l}\text { Concentrates on the quality of } \\
\text { services delivered }\end{array}$ \\
\hline $\begin{array}{l}\text { Intrinsic } \\
\text { enhancements }\end{array}$ & $\begin{array}{l}\text { Concentrates on the changing } \\
\text { environment or circumstances for } \\
\text { governmental stakeholders }\end{array}$ & $\begin{array}{l}\text { Concentrates on the changing } \\
\text { environment or circumstances for } \\
\text { non-governmental parties }\end{array}$ \\
\hline Transparency & $\begin{array}{l}\text { Concentrates on the access of } \\
\text { information or processes inside the } \\
\text { local government }\end{array}$ & $\begin{array}{l}\text { Concentrates on the external access } \\
\text { to information and processes } \\
\text { regarding service provision and } \\
\text { delivery }\end{array}$ \\
\hline Participation & $\begin{array}{l}\text { Concentrates on the frequency and } \\
\text { intensity of direct involvement of } \\
\text { internal stakeholders in decision } \\
\text { making or operation of government }\end{array}$ & $\begin{array}{l}\text { Concentrates on the frequency and } \\
\text { intensity of direct involvement of } \\
\text { external stakeholders in decision } \\
\text { making or operation of government }\end{array}$ \\
\hline Collaboration & $\begin{array}{l}\text { Concentrates on the improvement } \\
\text { of collaboration inside the local } \\
\text { government in terms of sharing } \\
\text { responsibility or authority for } \\
\text { governmental processes and actions }\end{array}$ & $\begin{array}{l}\text { Concentrates on the collaboration } \\
\text { between governmental and non- } \\
\text { governmental parties in terms of } \\
\text { sharing responsibility or authority } \\
\text { for governmental processes and } \\
\text { actions }\end{array}$ \\
\hline
\end{tabular}

\section{Research Design}

To understand how IoT creates public value, a qualitative study was carried out on the use of IoT in Estonian municipalities. The following section provides information on the research domain, data collection and analysis.

\subsection{Data Collection}

To paint a thorough picture of the use of IoT in public sector, the research concentrated on the use of IoT in Estonian municipalities. The data was collected between March and December 2017 through semi-structured interviews and supporting documentation reviews.

The research participants were found by first contacting all 202 municipalities in Estonia via e-mail regarding the use of IoT in public sector, the municipalities that had implemented IoT solutions were included to the study and the municipalities who were in the planning phase of IoT implementation or who had not implemented IoT solutions were excluded. Thus, ex ante descriptions of the predicted outcome of IoT were not included in the study. In total 81 municipalities replied, of whom 46 were included in 
the study. From those 46 municipalities, 67 participants were contacted and interviewed regarding the implemented IoT solutions. In some municipalities, more than one public official was interviewed due to a lack of involvement of the interviewee with other IoT solutions.

The interviews were conducted in person where possible, and over the phone in other circumstances. An interview guide was used to determine the course of the interviews, which included open-ended questions that allowed to include topics that were not predetermined by the interview guide. The type of questions in the interview guide included the type of solutions implemented, the outcomes of the solutions, collaboration with other stakeholders, the role of IoT, measurement techniques for the outcomes etc. In Table 2 an overview of the interview questions is presented. The interview guides were iteratively changed, according to the research conducted prior to the interviews - publicly available information on each municipality was gathered to determine the type of solutions introduced.

Table 2. Overview of interview questions.

\begin{tabular}{l}
\hline Interview question examples: \\
\hline What IoT solutions have been implemented? \\
\hline What has been the guiding principle behind the deployment of IoT? \\
\hline What benefits has the IoT brought? \\
\hline How has the IoT affected municipal processes? \\
\hline How do you verify the integrity of the collected data? \\
Why did the municipality decide to use the devices? \\
\hline Would it be financially beneficial for other municipalities to use these devices?
\end{tabular}

The interviews lasted between 20 and $120 \mathrm{~min}$, with an average of $57 \mathrm{~min}$. All interviews were audio recorded and later transcribed. The participants had been using IoT solutions from five months to five years - providing enough time to realize the value of IoT initiatives [24]. A summary of all interviews will be presented in Table 3.

Table 3. Summary of interviews.

\begin{tabular}{l|l}
\hline Public sector representatives & Total number of respondents \\
\hline Chief information officer & 7 \\
\hline Environmental and municipal advisor & 3 \\
\hline Head of economics department & 9 \\
\hline Head of public administrative unit & 4 \\
\hline Head of road maintenance & 1 \\
\hline Head of utilities & 7 \\
\hline Municipal mayor & 14 \\
\hline Municipal vice-mayor & 22
\end{tabular}


Supporting documentation such as procurement documents, public documents, and technical files were collected from governmental databases and online sources, e.g. municipal websites and from technology providers. Technical documentation was attained on both the system and the device where possible. Procurement documents which allowed to better understand the reasons and granularities of the implementation of any device were studied where possible. Public documents used included governmental reports, public statements etc. Secondary data sources were used to prepare for interviews, map government priorities etc. A summary of all additional procedures for data collection are presented in Table 4.

Table 4. Summary of data collection.

\begin{tabular}{l|l}
\hline \multicolumn{2}{l}{ Supporting documentation } \\
\hline Procurement documents & 118 \\
\hline Public documents & 173 \\
\hline Technical documents & 131 \\
\hline
\end{tabular}

\subsection{Data Analysis}

To analyse the data, the recommended procedures for qualitative research were followed to guide through the three steps of coding $[6,26]$. During the first round of coding an initial coding scheme was developed. As the research was concerned with identifying what public value IoT generates, the coding scheme was based on public value framework (See Table 1). During the second round of coding, examples of IoT generated public value were identified. As the study focused on how IoT has generated public value for the municipalities, the perspective of citizens and other stakeholders were considered through municipal perspective. The different dimensions were recorded altogether 2644 times. From the mentioned segments, 1481 concentrated on the external view. The remaining segments were divided between the internal dimensions. A summary of coded segments can be seen in Table 5.

Table 5. Summary of coded segments.

\begin{tabular}{l|c|c}
\hline Dimensions & Management (internal view) & Service delivery (external view) \\
\hline Efficiency & 431 & 339 \\
\hline Effectiveness & 298 & 405 \\
\hline Intrinsic enhancements & 67 & 74 \\
\hline Transparency & 113 & 301 \\
\hline Participation & 143 & 185 \\
\hline Collaboration & 111 & 177 \\
\hline Total & 1163 & 1481 \\
\hline
\end{tabular}


The third round of coding compared previously coded segments to summarize shared features and variance within and across research sites. Multiple data sources allowed to compare, contrast and triangulate data [26]. ATLAS.ti was used throughout the study for data analysis. Findings are presented in the following section.

\section{Empirical Analysis}

In recent years, IoT has gained traction in public discourse as IoT solutions are increasingly implemented. This research concentrates on the use of IoT in Estonian municipalities - studying the public value created by these solutions.

\subsection{Mapping the Estonian IoT Solutions}

IoT solutions can be implemented for virtually any purpose, however the study identified some core areas in which the implementation of IoT was more common, namely buildings and transportation. In total, 158 IoT solutions were implemented, from those, the study identified 30 different IoT solution types. Table 6 will present an overview of the implemented solutions and the number of municipalities that implemented those.

Table 6. Summary of IoT solutions.

\begin{tabular}{|c|c|c|c|}
\hline Area & $\begin{array}{l}\text { Number of } \\
\text { solutions } \\
\text { (percentage of all } \\
\text { solutions) }\end{array}$ & Overview of the solutions & $\begin{array}{l}\text { Examples } \\
\text { (number of } \\
\text { solutions) }\end{array}$ \\
\hline Buildings & $29(18.3 \%)$ & $\begin{array}{l}\text { Systems that include simple motion } \\
\text { sensors to regulate lightning to more } \\
\text { complex systems that regulate } \\
\text { window canopies depending on } \\
\text { lightning and temperature }\end{array}$ & $\begin{array}{l}\text { Heating system } \\
(9) ; \\
\text { Smart lightning } \\
(10) ; \\
\text { Ventilation } \\
\text { system (8); } \\
\text { Window canopies } \\
\text { (2) }\end{array}$ \\
\hline Infrastructure & $21(13.3 \%)$ & $\begin{array}{l}\text { Systems that include simple motion } \\
\text { sensors to turn on and regulate } \\
\text { lightning, to more complex systems } \\
\text { that regulate lightning depending on } \\
\text { vehicle speed and depending on } \\
\text { public transportation movement. } \\
\text { Pothole identification system allows } \\
\text { to identify and map the condition of } \\
\text { roads }\end{array}$ & $\begin{array}{l}\text { Pothole } \\
\text { identification } \\
\text { system (1); } \\
\text { Intelligent } \\
\text { lightning (20) }\end{array}$ \\
\hline Healthcare & $2(1.3 \%)$ & $\begin{array}{l}\text { Sensors collecting physical vitals and } \\
\text { transmitting them to healthcare } \\
\text { professionals and public officials. } \\
\text { Allows to notify of emergencies }\end{array}$ & $\begin{array}{l}\text { SOS-bracelets } \\
\text { (2) }\end{array}$ \\
\hline Security & $19(12 \%)$ & $\begin{array}{l}\text { Vehicle surveillance systems collect, } \\
\text { analyze and transmit information on }\end{array}$ & $\begin{array}{l}\text { Smoke detectors } \\
\text { (3); }\end{array}$ \\
\hline
\end{tabular}


Table 6. (continued)

\begin{tabular}{|c|c|c|c|}
\hline Area & $\begin{array}{l}\text { Number of } \\
\text { solutions } \\
\text { (percentage of all } \\
\text { solutions) }\end{array}$ & Overview of the solutions & $\begin{array}{l}\text { Examples } \\
\text { (number of } \\
\text { solutions) }\end{array}$ \\
\hline & & $\begin{array}{l}\text { vehicles. Smoke detectors and } \\
\text { surveillance systems allow remote } \\
\text { access and improved detection }\end{array}$ & $\begin{array}{l}\text { Surveillance } \\
\text { system (7); } \\
\text { Vehicle } \\
\text { surveillance } \\
\text { system (9) }\end{array}$ \\
\hline Transportation & $49(31 \%)$ & $\begin{array}{l}\text { Connected buses and fleet telematics } \\
\text { allow remote monitoring of location, } \\
\text { performance and behavior of vehicles } \\
\text { Remote passenger validation system } \\
\text { allows to validate passengers and } \\
\text { track their movements } \\
\text { Traffic and pedestrian/cyclist counter } \\
\text { allows to count the number of } \\
\text { individuals and various other } \\
\text { elements, e.g. their speed and whether } \\
\text { they wear bicycle helmets } \\
\text { Smart parking allows to track and } \\
\text { visualize the available parking spaces }\end{array}$ & $\begin{array}{l}\text { Connected buses } \\
\text { (5); } \\
\text { Fleet telematics } \\
(34) ; \\
\text { Pedestrian/cyclist } \\
\text { counter (2); } \\
\text { Remote passenger } \\
\text { validation system } \\
\text { (1); } \\
\text { Self-driving buses } \\
\text { (1); } \\
\text { Smart bicycle } \\
\text { parking (3); } \\
\text { Traffic counter (3) }\end{array}$ \\
\hline Utilities & $23(14.6 \%)$ & $\begin{array}{l}\text { Array of sensors that allow to } \\
\text { improve the processes and automate } \\
\text { the monitoring and maintenance of } \\
\text { utility systems, e.g. geothermal } \\
\text { systems, garbage transfer stations } \\
\text { and wastewater treatment plants. } \\
\text { Smart meters allow to collect and } \\
\text { analyze water consumption and } \\
\text { automate various processes, e.g. } \\
\text { billing and detection of leakage }\end{array}$ & $\begin{array}{l}\text { Biomass heating } \\
\text { systems (5); } \\
\text { Garbage transfer } \\
\text { station (1); } \\
\text { Garbage bins (2); } \\
\text { Geothermal } \\
\text { systems (6); } \\
\text { Water meters (5); } \\
\text { Water plant (2); } \\
\text { Wastewater } \\
\text { treatment plant } \\
(2)\end{array}$ \\
\hline $\begin{array}{l}\text { Weather and } \\
\text { environmental } \\
\text { monitoring }\end{array}$ & $15(9.5 \%)$ & $\begin{array}{l}\text { Array of sensors that collect and } \\
\text { analyze environmental information, } \\
\text { such as water and air quality, } \\
\text { temperature and constituents. The } \\
\text { system alerts when these values } \\
\text { exceed a set threshold }\end{array}$ & $\begin{array}{l}\text { Air quality } \\
\text { sensors (3); } \\
\text { Noise sensors (1); } \\
\text { Pavement sensors } \\
(1) ; \\
\text { Snow monitoring } \\
(3) \text {; } \\
\text { Water monitoring } \\
(3) \text {; } \\
\text { Weather Stations } \\
\text { (4) }\end{array}$ \\
\hline
\end{tabular}


Table 7. Number of solutions with identified public value.

\begin{tabular}{l|l|l|l}
\hline \multirow{2}{*}{ Dimensions } & \multicolumn{2}{|l|}{ Number of solutions } & $\begin{array}{l}\text { Total number of } \\
\text { solutions }\end{array}$ \\
\cline { 2 - 4 } & $\begin{array}{l}\text { Management } \\
\text { (internal view) }\end{array}$ & $\begin{array}{l}\text { Service delivery } \\
\text { (external view) }\end{array}$ & 75 \\
\hline Efficiency & 68 & 36 & 94 \\
\hline Effectiveness & 64 & 53 & 19 \\
\hline $\begin{array}{l}\text { Intrinsic } \\
\text { enhancements }\end{array}$ & 16 & 7 & 67 \\
\hline Transparency & 28 & 64 & 32 \\
\hline Participation & 24 & 17 & 45 \\
\hline Collaboration & 38 & 42 & \\
\hline
\end{tabular}

Table 7 presents a summary of solutions where public value was identified. A solution could simultaneously provide public value in many dimensions, for example there were 75 solutions which generated efficiency, from those solutions, 68 produced public value for management and 36 solutions produced public value in service delivery.

The following part presents how IoT impacted the six public value mechanisms, drawing on specific IoT implementation examples for illustration, see Table 6.

\subsection{Efficiency}

The study identified that $64.5 \%$ of solutions (102 solutions) had efficiency as their primary desired outcome. From all solutions, $47.5 \%$ of solutions (75 solutions) identified efficiency as an achieved outcome. While reducing costs was the main consideration during the procurement, it was difficult for municipalities to isolate the effects and measure the outcome. Consequently, improvements in efficiency were visible in terms of productivity, most commonly through reduced time and improved communication. The devices allowed municipal employees to work everywhere at any time without physically being present. This allowed to get a better and timelier overview of work processes, coordinate and reduce the workload. The devices allowed to verify whether service contractors and systems worked as needed. Through automatic analyzation it was possible to identify deviations that would have otherwise remained unnoticed. Even though IoT in some instances increased the hourly rate of work, the number of hours spent decreased. For instance, the fleet telematics enabled maintenance managers to re-route optimal vehicles, better maintain roads, and reduce the time vehicles were standing idle. Commonly implemented solutions included fleet telematics which helped to resolve disputes among stakeholders and reduced strain on municipalities to provide timely information to citizens. At the forefront of cost cutting were solutions related to energy consumption reduction, however the use of motion and $\mathrm{CO}_{2}$ sensors were difficult to utilize to their fullest potential due to the human element which interfered with the automatization, i.e. people opened windows instead of allowing the ventilation system to operate independently. To counter the human element, various approaches were taken, from employee training to changes in the 
physical environment, i.e. making it impossible to open windows. Still, cost efficiency remained difficult to achieve and often even harder to measure due to the changing environmental elements, e.g. changing weather conditions made it hard to compare changes on yearly basis.

\subsection{Effectiveness}

Improved effectiveness was the most commonly achieved outcome from the use of IoT, identified as an achieved outcome in $59.5 \%$ of solutions (94 solutions). Although the implementation of IoT systems commonly had a goal to gain efficiency, especially in financial terms, most highly valued outcomes identified by the municipalities were derived from improved effectiveness. The devices allowed public officials to reduce unnecessary work (avoid personal interaction, provide easier access to information, allow for increased control, and offer convenience), and improve decision making and work outcomes (services could be personalized and provided in timely manner, investments were more targeted). Data provided by the sensors allowed to evaluate the work of devices, e.g. heating systems and private contractors, e.g. garbage disposal providers. In case of deviations, municipalities were notified of the changes. This allowed to improve the quality of service delivery and through that reduce costs as it took less time to achieve the intended outcome. Controversially, the devices often proved to be more efficient in identifying the shortcomings in effectiveness rather than aiding in improving them. For example, the pothole identifying system allowed to map the problematic roads, however the information did not necessarily lead to improvements as the processes surrounding the road management were not improved to reflect the capabilities of the data generated by IoT. As an example, a municipality used the system to identify potholes, but made no changes to organizational operation and road management strategy.

\subsection{Intrinsic Enhancements}

Intrinsic enhancements were identified as the least important outcome from the use of IoT, only identified in $12 \%$ of solutions (19 solutions) as an achieved outcome. In majority of cases intrinsic enhancements were not considered during the implementation, but rather emerged as unexpected outcomes during the use of the devices. Intrinsic enhancements considered here, i.e. less redundant work practices regarding communication, were by nature silent outcomes, as they were experienced by all, but the highest improvements would be expected at service level and for consumers, but not necessarily by service providers - in this case municipalities. This in turn contributed to the low priority of intrinsic enhancements.

\subsection{Transparency}

Improved transparency was identified as an achieved goal of IoT in $42.4 \%$ of solutions (67 solutions). IoT allowed municipalities and their employees to defend their decision making, overcome false accusations (reduce the impact of political loyalty), and helped to avoid unethical and unlawful actions, i.e. provide equal treatment for all stakeholders 
and protect individual rights. Through making information available for the public, municipalities could reduce their workload, make more calculated decisions, foster trust and accountability, and receive valuable feedback on their services. When citizens demanded information, the public official could rely on IoT generated data to provide up-to-date information. Municipalities could further control whether service contractors worked in an agreed upon amount and according to contracts - helping to contribute to reliability and stability of service provision. This allowed to avoid conflicts between the municipality and the service contractors, paved the way towards a trusting relationship and enhanced cooperation. However, transparency remained the most controversial outcome of IoT implementation, as improvements in transparency generated countless unforeseen difficulties that resulted in reversing the improved work practices to the previous mode of operation. To illustrate, citizens started to ambush winter road maintenance vehicles when the information of the vehicle movement was made available online. This resulted in an overall stigma for improvements in transparency, as failures in municipal management could have given a political disadvantage in upcoming elections, or provided a competitive advantage for neighboring municipalities.

\subsection{Participation}

Improved participation was identified as an outcome of IoT implementation in $20.3 \%$ of solutions (32 solutions). Improved participation was never the primary intent of IoT implementation, however municipalities experienced improved participation both from local government and from external stakeholders. From the improvements in the dimension of participation, 24 solutions identified improvements on an internal level, improvements on an external level were visible in 17 solutions. However, silos existed whereby internal actors from different departments were not invested in the improvement of government operation even if capabilities to support it were created. Circumstances where internal stakeholders were involved consisted of instances where the system directly affected them in terms of their private or working life. While external stakeholders were more highly interested in decision making and in the operation of government, it was generally not welcomed by the government officials. Instead the generated data was used to support the sole decisions of managers involved with the IoT implementation, leaving out the external actors - mistrust and uncooperative behaviors remained wide-spread.

\subsection{Collaboration}

Improved collaboration was identified as an achieved outcome in $28.5 \%$ of solutions (45 solutions). Collaboration was wide-spread both internally and externally. However, in majority of cases, collaboration was required for IoT implementation, but not necessarily fostered it. For instance, vehicle surveillance systems required police involvement due to the data protection acts. Collaboration was often present before the implementation of IoT, however IoT greatly enhanced the level of involvement and supported influx of more relevant information. For instance, when municipalities noticed that the quality of work was consistently worse for some drivers, e.g. garbage 
removal, they notified the private contractors, which allowed to improve the service delivery. Due to the availability of information, collaboration emerged between public officials and private contractors. For instance, when a technician previously had to be present to fix a biomass heating system, then following IoT implementation public officials took increasingly care of the maintenance. Similarly, when there were problems with private contractors' work, public officials directly contacted the people responsible. IoT provided capabilities that made municipalities adopt a more active role in service delivery. Indeed, municipalities had started to consider providing services without public-private collaboration. For instance, in winter road maintenance IoT created a situation where the public official became more actively invested in the maintenance than the private maintenance manager. Citizens on the other hand were involved in government operation through actively evaluating the available information, notifying of shortcomings. When services did not meet citizen expectations or citizens needed a custom service, they contacted for improvements. While citizens were involved, their participation in the governance was not wide-spread. With regards to this, citizens had limited impact, i.e. did not contribute, on the functioning of government.

\section{Discussion}

Previous research indicates that efficiency is typically the primary goal of IT initiatives [11], which also holds proof here. However, the findings suggest that public organizations are increasingly focusing their attention on other dimensions besides efficiency, most commonly on effectiveness and transparency. This goes against the typical notion of IoT which is mainly articulated in terms of economic value [31]. Municipalities included in the study often considered other dimensions as the most sought after, neglecting efficiency as an important outcome even if an element of efficiency, e.g. time or cost, was stated as the primary implementation goal. By contrast other elements, most notably effectiveness and transparency, were increasingly derived as outcomes of these government initiatives. With regards to this, IoT allows to create public value beyond efficiency.

The findings suggest that while collaboration, transparency and participation generated public value, they should not be viewed as an administrative goal [14]. The opposing needs of stakeholders could create disturbances that could negatively affect the effectiveness and efficiency of public organizations. Harrison et al. [14] argued that transparency, participation and collaboration should be viewed as means toward desirable ends. The findings of this study suggest that without clear goal, public organizations should refrain from making information publically available. Controlled secrecy in some instances could prove more beneficial for deriving public value. For instance, available information was used to interfere with service provision and how the system operated, e.g. stopping winter road maintenance vehicles or opening windows to regulate temperature. Hence, each case should be closely evaluated to determine whether external and/or internal actors should be engaged in the operation of government. While it is easier to continue in secrecy, transparency and collaboration had a strong effect on achieving public values from other dimensions, e.g. effectiveness and 
efficiency, which otherwise were not achieved. Thus, government initiatives should be directed to stakeholders that allow to achieve the optimum public value.

The study illustrates that while some solutions are more beneficial than others, deriving public value from IoT initiatives requires public organizations to use the generated data to change how they operate. While the most substantial changes require IoT technology, management and policy changes make the biggest difference in the derived outcome of IoT. Using smart garbage bins or fleet telematics without changing how public organizations operate brought forward positive changes, but substantial benefits, required a change in management and policy. Public organizations had to change how they operate through using the devices and generated data in a unique way. For instance, they could continue to use fleet telematics for surveillance of vehicles, however when incorporating the generated data in investments, decision making or fostering closer collaboration with private organizations, the most substantial benefits occurred. As a result, the findings suggest that most public organizations are handling post-implementation phase of IoT inadequately, most notably regarding what to do with the produced data.

The research indicates that public organizations are not evaluating the outcome of IoT implementation. Throughout the study, rather few organizations had performed a formal evaluation of an IoT initiative. Similarly, the study by Jones and Hughes [17] identified that public organizations tended to rely on an assessment whether the technology works, rather than considering the social impact or value of the technology. If the outcome was evaluated, it was done through the prism of efficiency in an abstract manner. Without the formal assessment, it becomes difficult for public organizations to demonstrate the public value of IoT. Relying on abstract measurement systems, such as the number of complaints by citizens, could be a viable predictor of the success of an initiative, but it neglects the more substantial outcomes the technology could produce. There thus remains a need to explore how IoT created public value can be measured and is measured by public organizations. As the previous findings suggest, other aspects besides efficiency are gaining traction in IoT generated public value, the study concludes that the analysis of IoT should also consider other value generators besides efficiency when evaluating the solution. Evaluation and presentation of the different forms of public value generated by IoT could allow public organizations to avoid public scrutiny and improve the utilization of IoT. Especially, as many IoT projects were sealed off from external stakeholders due to the fear of criticism and political harm.

\section{Conclusion}

To conclude, IoT has the capability to create public value and the intended public value dimensions have widened from the goal of improved efficiency. There has been a shift in value creation with other goals and outcomes such as effectiveness, transparency and collaboration gaining increased presence. Furthermore, the data suggest that the evaluation of IoT remains largely insufficient, and is mostly done abstractly or through financial metrics alone, which inhibits capturing the full potential of IoT. Public value derivation cannot rest on the implementation of IoT solutions alone, but must include 
improvements in management and policy according to the ample data generated by the devices.

Finally, there are limitations to be acknowledged. First, the research studied public value through the perspective of public organizations, however public values are rarely identical for stakeholders. Thus, additional research is required to study public value from the perspective of stakeholders like citizens and private organizations. Secondly, evaluating public value is never an easy task and more longitudinal studies could offer further in-depth understanding of public value created by IoT.

\section{References}

1. Agarwal, R., Lucas, H.C.: The information systems identity crisis: focusing on highvisibility and high-impact research. MIS Q. 29(3), 381-398 (2005)

2. Atzori, L., Iera, A., Morabito, G.: The internet of things: a survey. Comput. Netw. 54(15), 2787-2805 (2010)

3. Bannister, F., Connolly, R.: The trouble with transparency: a critical review of openness in egovernment. Policy Internet 3(1), 1-30 (2011)

4. Bradley, J., Reberger, C., Dixit, A., Gupta, V.: Internet of everything: a $\$ 4.6$ trillion publicsector opportunity. Cisco (2013)

5. Cordella, A., Bonina, C.M.: A public value perspective for ICT enabled public sector reforms: a theoretical reflection. Gov. Inf. Q. 29(4), 512-520 (2012)

6. Eisenhardt, K.M.: Building theories from case study research. Acad. Manag. Rev. 14(4), 532-550 (1989)

7. European Commission: Definition of a research and innovation policy leveraging cloud computing and IoT combination. Digital Single Market (2015)

8. European Commission: The Internet of Things. https://ec.europa.eu/digital-single-market/en/ policies/internet-things. Accessed 01 Feb 2018

9. Friedewald, M., Raabe, O.: Ubiquitous computing: an overview of technology impacts. Telemat. Inform. 28(2), 55-65 (2011)

10. Gil-Garcia, J.R., Chengalur-Smith, I., Duchessi, P.: Collaborative e-Government: impediments and benefits of information-sharing projects in the public sector. Eur. J. Inf. Syst. 16 (2), 121-133 (2007)

11. Gil-Garcia, J.R., Zhang, J., Puron-Cid, G.: Conceptualizing smartness in government: an integrative and multi-dimensional view. Gov. Inf. Q. 33(3), 524-534 (2016)

12. GrowthEnabler: Market Pulse Report, Internet of Things (IoT) (2017)

13. Gubbi, J., Buyya, R., Marusic, S., Palaniswami, M.: Internet of things (IoT): a vision, architectural elements, and future directions. Future Gener. Comput. Syst. 29(7), 1645-1660 (2013)

14. Harrison, T.M., et al.: Open government and e-government: democratic challenges from a public value perspective. Inf. Polity 17(2), 83-97 (2012)

15. Hermann, M., Pentek, T., Otto, B.: Design principles for Industrie 4.0 scenarios. In: The Proceedings of the 49th Hawaii International Conference on System Sciences, Koloa, HI, USA (2016)

16. Johansen, C., Culp, B., Mora, M.: Cisco survey reveals close to three-fourths of IoT projects are failing, Cisco (2017)

17. Jones, S., Hughes, J.: Understanding IS evaluation as a complex social process: a case study of UK local authority. Eur. J. Inf. Syst. 10(4), 189-203 (2001) 
18. Jørgensen, T.B., Bozeman, B.: Public values: an inventory. Adm. Soc. 39(3), 354-381 (2007)

19. Kagermann, H., Wahlster, W., Helbig, J.: Recommendations for implementing the strategic initiative Industrie 4.0. (2013)

20. Krishnamurthy, R., Desouza, K.C.: Tony Parham: fostering innovation DNA in the commonwealth of Massachusetts (2014)

21. Kohli, R., Grover, V.: Business value of IT: an essay on expanding research directions to keep up with the times. J. Assoc. Inf. Syst. 9(2), 23-39 (2008)

22. Lee, J., Lee, H.: Developing and validating a citizen-centric typology for smart city services. Gov. Inf. Q. 31(1), 93-105 (2014)

23. Lee, J., Lee, H.: The Internet of Things (IoT): applications, investments, and challenges for enterprises. Bus. Horiz. 58(4), 431-440 (2015)

24. Marchand, D.A., Kettinger, W.J., Rollins, J.D.: Information orientation: people, technology and the bottom line. Sloan Manag. Rev. 41(4), 69-80 (2000)

25. McKinsey: The Internet of Things: Mapping the Value Beyond the Hype. McKinsey Global Institute (2015)

26. Miles, M.B., Huberman, A.M., Saldana, J.: Qualitative Data Analysis: A Methods Sourcebook, 3rd edn. SAGE Publications, Thousand Oaks (2014)

27. Moore, M.H.: Creating Public Value: Strategic Management in Government. Harvard University Press, Cambridge (1995)

28. Nam, T., Pardo, T.A.: The changing face of a city government: a case study of Philly311. Gov. Inf. Q. 31(1), 1-9 (2014)

29. Pang, M.S., Lee, G., DeLone, W.H.: IT resources, organizational capabilities, and value creation in public-sector organizations: a public-value management perspective. J. Inf. Technol. 29(3), 187-205 (2014)

30. Pereira, G.V., Macadar, M.A., Luciano, E.M., Testa, M.G.: Delivering public value through open government data initiatives in a Smart City context. Inf. Syst. Front. 19(2), 213-229 (2016)

31. Prasopoulou, E.: A half-moon on my skin: a memoir on life with an activity tracker. Eur. J. Inf. Syst. 26(3), 287-297 (2017)

32. Singha, D., Tripathi, G., Jara, A.J.: A survey of Internet-of-Things: future vision, architecture, challenges and services. In: Proceedings on 2014 IEEE World Forum on Internet of Things (WF-IoT) (2014)

33. Shin, D.-H.: Ubiquitous city: urban technologies, urban infrastructure and urban informatics. J. Inf. Sci. 35(5), 515-526 (2009)

34. Sundmaeker, H., Guillemin, P., Friess, P., Woelffle, S.: Vision and challenges for realising the Internet of Things. Eur. Comm. 3, 34-36 (2010)

35. Zanella, A., Bui, N., Castellani, A., Vangelista, L., Zorzi, M.: Internet of Things for smart cities. IEEE Internet Things J. 1(1), 22-32 (2014)

36. Zhang, J., Puron-Cid, G., Gil-Garcia, J.R.: Creating public value through open government: perspectives, experiences and applications. Inf. Polity 20(2), 97-101 (2015)

37. Teo, T., Srivastava, S., Jiang, L.: Trust and electronic government success: an empirical study. J. Manag. Inf. Syst. 25(3), 99-131 (2008)

38. Vicente, P., Lourdes, T., Royo, S.: Are ICTs improving transparency and accountability in the EU regional and local governments? An empirical study. Publ. Adm. 85(2), 449-472 (2007) 
Open Access This chapter is licensed under the terms of the Creative Commons Attribution 4.0 International License (http://creativecommons.org/licenses/by/4.0/), which permits use, sharing, adaptation, distribution and reproduction in any medium or format, as long as you give appropriate credit to the original author(s) and the source, provide a link to the Creative Commons license and indicate if changes were made.

The images or other third party material in this chapter are included in the chapter's Creative Commons license, unless indicated otherwise in a credit line to the material. If material is not included in the chapter's Creative Commons license and your intended use is not permitted by statutory regulation or exceeds the permitted use, you will need to obtain permission directly from the copyright holder. 